Proc. Estonian Acad. Sci. Geol., 2001, 50, 1, 5-23

\title{
FACIES AND STRATIGRAPHY OF THE MIDDLE CARADOC MIXED SILICICLASTIC-CARBONATE SEDIMENTS IN EASTERN BALTOSCANDIA
}

\author{
Leho AINSAAR and Tõnu MEIDLA \\ Institute of Geology, University of Tartu, Vanemuise 46, 51014 Tartu, Estonia; lainsaar@ut.ee \\ Received 17 April 2000, in revised form 31 July 2000

\begin{abstract}
The middle Caradoc sedimentary facies transitions and dynamics in southern Estonia and the Gotland area in the Keila, Oandu, and Rakvere stages are described. Grain size analysis of the noncarbonate component demonstrates differences between the major confacies belts. A new name, the Variku Formation, is proposed for a rock unit of intercalating quartzose siltstones, claystones, and marls in southern Estonia, and the late Keila to Rakvere age of this unit is suggested by ostracode data. The change of the deposition type in the Caradoc Baltic Basin lasted for a considerable time and can be characterized by a sequence of successive climatic, isotopic, and eustatic events and change in sedimentary material input. Complex reasons related to the continental drift and continental glaciation are proposed for the Caradoc turnover.
\end{abstract}

Key words: Ordovician, Caradoc, lithofacies zones, mixed siliciclastic-carbonate sediments, Estonia, Sweden.

\section{INTRODUCTION}

The Baltica palaeocontinent suffered drastic climatic changes during the Ordovician. It drifted from the southern high latitudes to the tropical realm (Torsvik et al. 1996), and the middle Ordovician (Arenig-Llanvirn) temperate climate carbonate sedimentation changed to the warm water type carbonate sedimentation. In the Baltoscandian Palaeobasin the most significant changes took place in the middle Caradoc, in Keila-Rakvere time (Jaanusson 1973; Nestor \& Einasto 1997), when the unification stage in the basin evolution was replaced by the differentiation stage (Nestor 1990; Nestor \& Einasto 1997). Major sedimentological and faunal changes, shifts in the isotopic composition of seawater and sea level fluctuations, recorded in the middle Caradoc of the East Baltic, are thought to be related to the global oceanographic event (Ainsaar et al. 1999a, 1999b; Meidla et al. 1999).

The aim of this study was to describe the middle Caradoc facies dynamics and facies transitions between the onshore North Estonian Confacies Belt and 
the Livonian Tongue, an eastern gulf-like extension of the offshore Central Baltoscandian Confacies Belt. Main interest was focused on the deposition of mixed fine siliciclastic-carbonate sediments in southern Estonia and the Gotland area (Gotland Island, Gotska Sandön, and the surrounding submarine exposures), in the transitional zone between the confacies belts. The composition of the noncarbonate component in the rocks was under particular attention, as variation in its content and character can be interpreted in the context of the sedimentary environments and terrigenous input history.

\section{MATERIAL AND METHODS}

The middle to late Caradoc interval of four core sections from southern Estonia and one from Gotland was sampled and described (Fig. 1). Eighty-seven samples (44 from the Ristiküla-174 section, 9 from the Pärnu-6 section, 3 from the Tartu-453 section, 25 from the Valga-10 section, and 6 from the Grötlingbo- 1 section) were subjected to sedimentological analysis. The carbonate component of the samples with the initial weight of 20-50 g was dissolved in diluted (3.5\%) hydrochloric acid. Insoluble residue (i.r.) was fractionated by gravity sedimentation and sieving into the fractions of $\langle 2,2-8,8-16,16-63$, and $>63 \mu \mathrm{m}$. Grain size data of i.r. from the Grötlingbo core were considered unreliable because of higher compaction of the

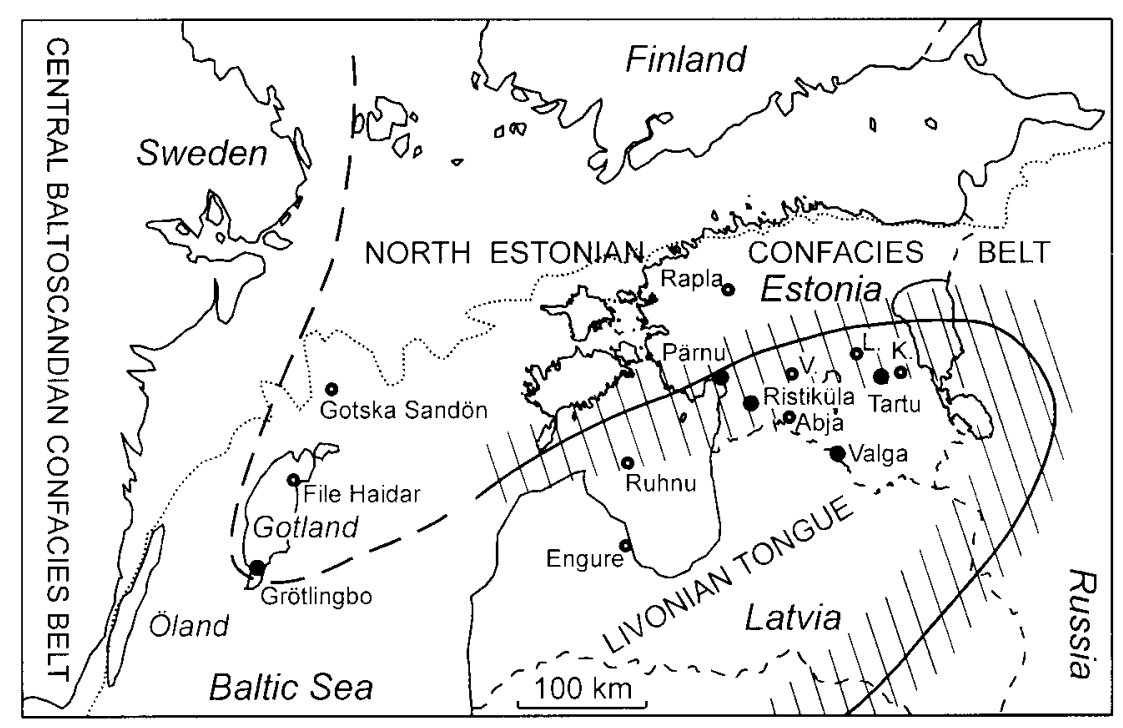

Fig. 1. Location of core sections (filled rings - sampled sections; empty rings - other sections) and the approximate boundary of post-Tremadoc Ordovician confacies belts (solid and dashed lines, after Jaanusson 1976; striped area - transitional facies zone after Põlma 1982). Dotted line northern limit of the distribution of Ordovician sedimentary rocks. Abbreviations: K., Kaagvere; L., Laeva; V., Viljandi. 
rocks, leading to diagenetic bounding of noncarbonate particles. Insoluble residues of two argillite samples of the Mossen Formation of the Valga core were treated with $\mathrm{H}_{2} \mathrm{O}_{2}$ to remove organic material prior to granulometric analysis.

Semiquantitative data on the mineralogical composition of the carbonate component in the whole-rock samples were obtained by X-ray diffraction (XRD) using the DRON-3M diffraction system (Mn-filtered $\mathrm{Fe}-K \alpha$ radiation). Calcite $3.04 \AA$ and dolomite $2.89 \AA$ XRD peak intensities were corrected with the proportional factors 0.7 and 0.6 , respectively, for calculating the calcite/dolomite ratio. Six thin sections (2 from Ristiküla, 2 from Tartu, and 2 from Grötlingbo) were prepared from samples of the siltstone intervals, and polished, carbon coated surfaces for scanning electron microscope and energy dispersive spectrometer analyses were prepared. The electron images and energy dispersive spectrometer were used for analyses of selected areas of thin sections and for identification of the individual crystals or grains. Ostracodes were separated and identified from the samples of Estonian core sections. The sedimentological data of the Ristiküla section and ostracode data of the Ristiküla, Tartu, and Pärnu sections are partly published in Ainsaar et al. (1996, 1999b) and Põldvere et al. (1998).

\section{COMPOSITION OF THE NONCARBONATE COMPONENT}

The Caradoc carbonate rocks of the study area are rich in siliciclastic material, mainly mud (clay and silt). Carbonate material is generally prevailing in argillaceous limestones and marls common in this interval (Adze and Kahula formations). Some types of rock are predominantly siliciclastic, with a minor carbonate content (Blidene and Mossen formations, the new Variku Formation, defined here - see below; Fig. 2). The exception is the generally calcareous Rägavere Formation with an only minor supplement of the noncarbonate component.

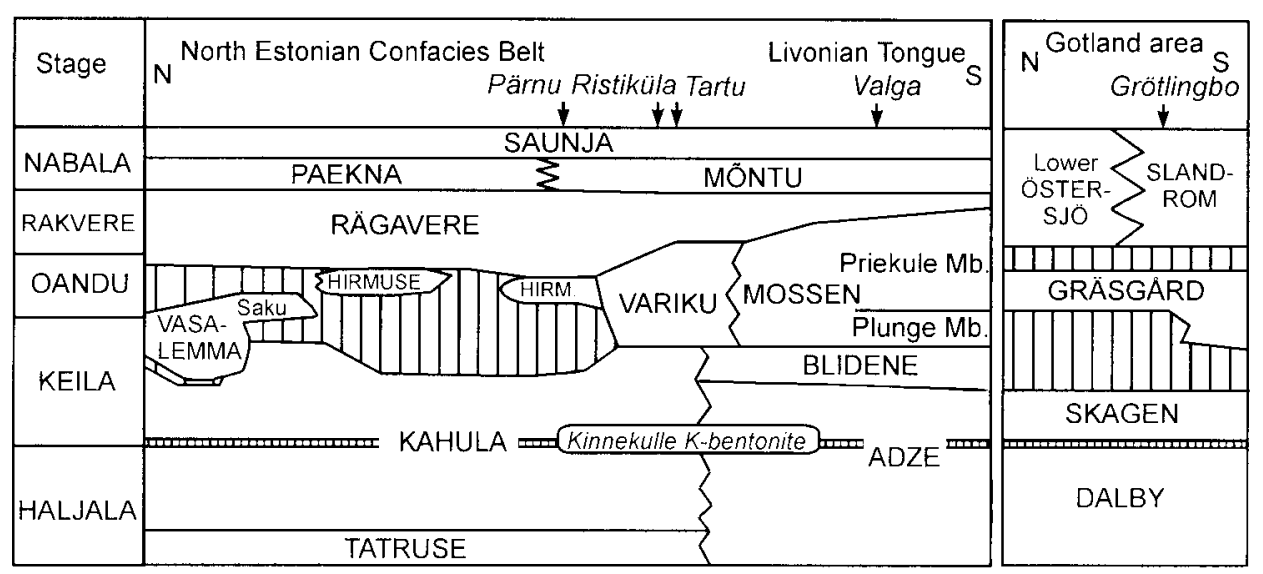

Fig. 2. Stratigraphy of the Haljala, Keila, Oandu, and Rakvere stages in Estonia (modified from Männil \& Meidla 1994) and Gotland (from Nõlvak \& Grahn 1993). Vertical ruling - hiatus; arrows point at the relative position of the studied core sections. 
The content of i.r. in the Kahula Formation in northern Estonia is changing cyclically from about 5\% to 30\%. The i.r. of wackestones of the Kahula Formation in the Pärnu and Ristiküla sections and of the Adze Formation in the Valga section contains about $50 \%$ clay fraction ( $<2 \mu \mathrm{m}$; mainly illite), $20-30 \%$ fine silt $(2-16 \mu \mathrm{m})$, and 20-30\% medium and coarse silt (16-63 $\mu \mathrm{m}$; quartz and K-feldspar; Fig. 3; Ainsaar et al. 1996). According to Põlma et al. (1988), the i.r. of wackestones of the Kahula Formation in northwestern Estonia has the prevailing grain size of $<10 \mu \mathrm{m}$. The uppermost part of the Kahula Formation in the Ristiküla section (transitional zone) is characterized by intercalating argillaceous limestone and marl, both with an elevated content (30-60\%) of medium and coarse silt as compared to the underlying limestone. The Blidene Formation in the Valga section is composed mainly of clay and fine silt with a low content of medium and coarse silt $(16-63 \mu \mathrm{m}$; 0-20\% i.r.) and with a carbonate content of 30-40\% (Fig. 3).

In the transitional zone and within the Livonian Tongue the uppermost part of the Keila Stage and the Oandu Stage are represented by predominantly siliciclastic rocks (50-90\% of the rock is noncarbonate). Insoluble residue of these rocks in the Ristiküla and Tartu core sections contains medium and coarse silt, mainly quartz, at a concentration of $20 \%$ (in clay beds) to $80 \%$ (in siltstone beds). The content of fine sand $(63-125 \mu \mathrm{m})$ reaches 10\% (Ainsaar et al. 1996; Fig. 3). In thin sections of the siltstone abundant angular quartz grains with a diameter of $30-80 \mu \mathrm{m}$ together with minor K-feldspar grains of the same size can be recognized in the surrounding clay matrix (Pl. I, figs. 4, 5). Mineral i.r. fraction of the organicrich argillite and carbonaceous clay of the Mossen Formation in the Valga section contains generally less than $20 \%$ medium and coarse silt and less than $1 \%$ sand. Only in the lowermost bed of the Priekule Member the content of the medium and coarse silt fraction reaches $25-30 \%$ of the total i.r.

The Hirmuse Formation (Oandu Stage) has the i.r. content of 5-70\% in northeastern Estonia (Põlma et al. 1988) and 20-50\% in the Pärnu section. In both cases, i.r. is mainly represented by clay and fine silt fraction (Põlma et al. 1988; Fig. 3). The micritic limestones of the Rägavere Formation in northern Estonia contain a minor amount (usually less than 10\%) of noncarbonate material. Similar limestones of the Rägavere and Mõntu formations in the transitional zone (Ristiküla section) and in the northern part of the Livonian Tongue (Valga section) contain up to $20 \%$ i.r., mainly clay and fine silt in the areas listed above (Fig. 3).

The Gräsgård Siltstone in the Gotland area generally resembles the siltstone beds in southern Estonia in respect of the noncarbonate component. The i.r. content of the Gräsgård Siltstone is $41-71 \%$ in Öland boulders (Martna 1955) and $47-76 \%$ in the Grötlingbo core section (4 analyses). In thin sections of the Grötlingbo samples (Pl. I, figs. 6,7) the noncarbonate material of the Gräsgård Siltstone consists mainly of quartz, but is finer (grain size $20-50 \mu \mathrm{m}$ ) than in siltstones of the Ristiküla and Tartu sections. 

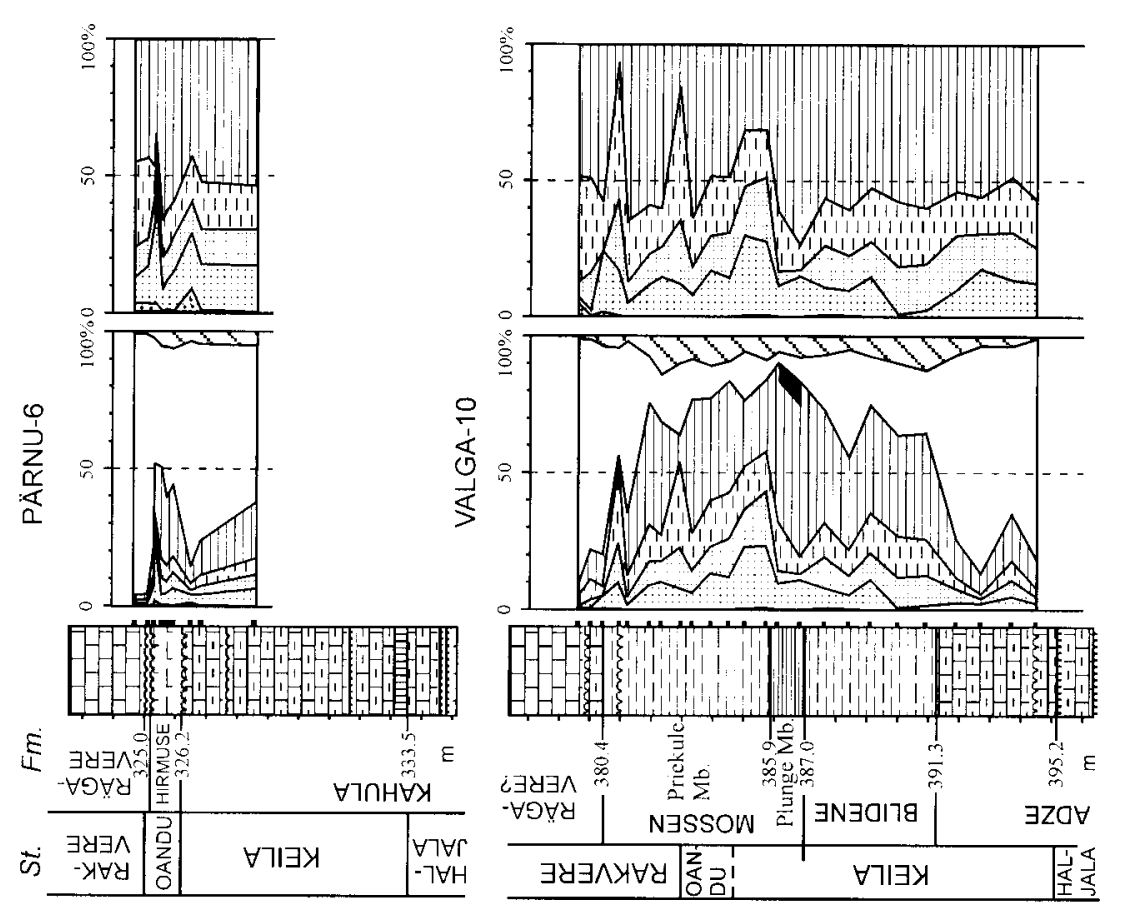

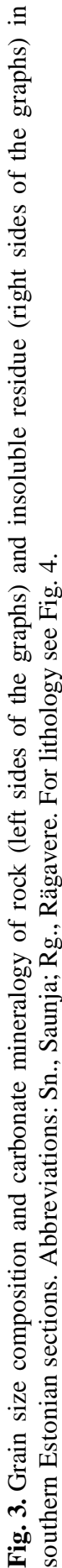


PLATE I
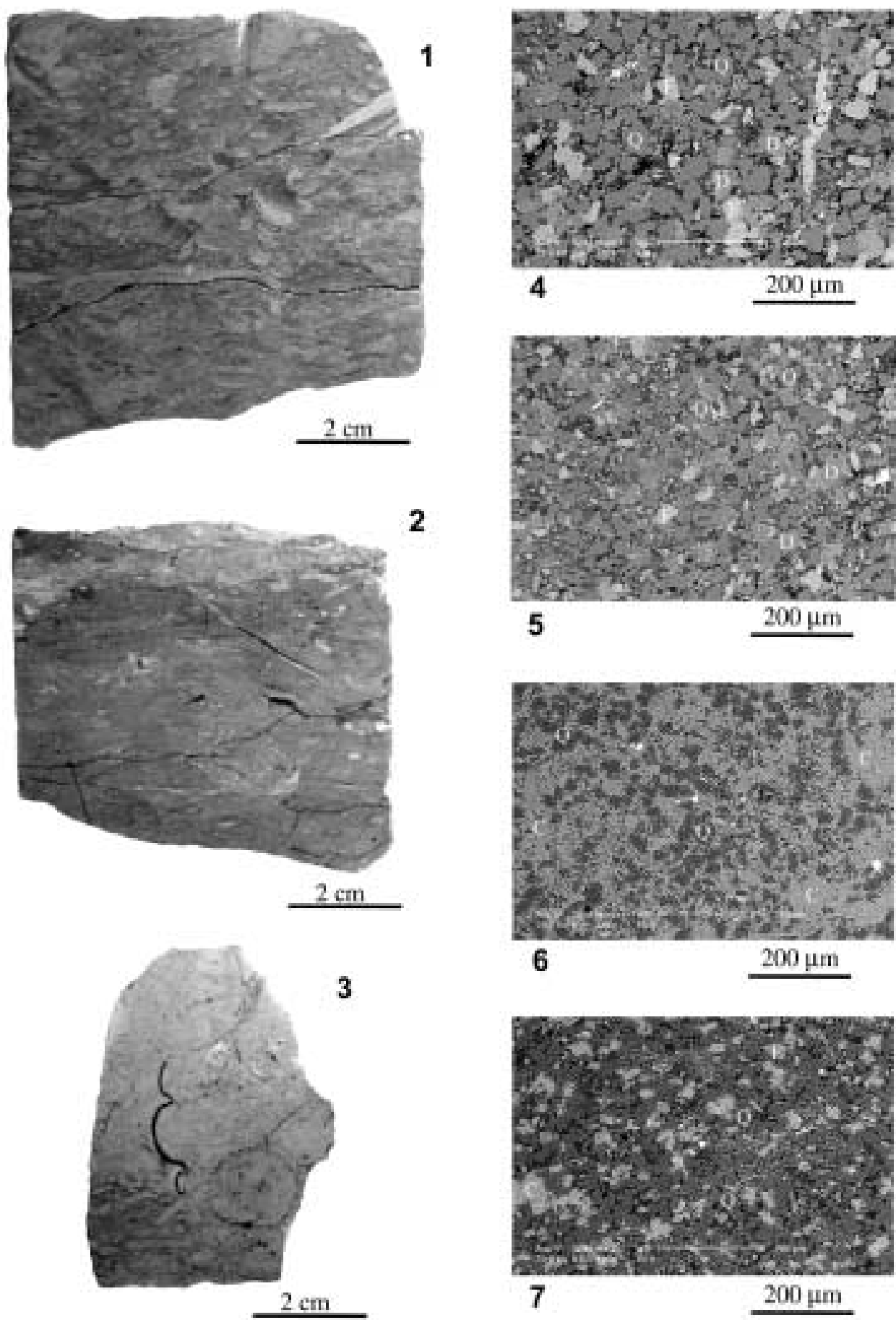

6

$200 \mu \mathrm{m}$

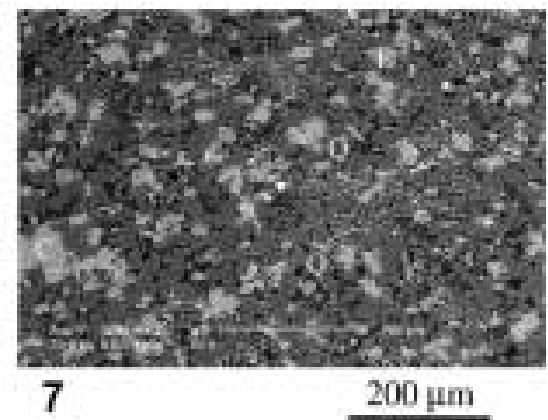




\section{VARIKU FORMATION}

In southern Estonia, in the zone of confacies transition, the argillaceous limestones of the Kahula Formation are overlain by siliciclastic-dominated rocks (claystones, marls, and siltstones; Ainsaar et al. 1996, 1999b). In the recent correlation charts (Männil \& Meidla 1994; Nõlvak 1997) the Lukštai Formation is shown in a similar stratigraphic position. However, the last formation is defined in the Central Lithuanian Depression as the alternation of marl and biomorphic limestones (Laškov et al. 1984). This type of rock is definitely missing in Estonia and the core intervals earlier distinguished as the Lukštai Formation should be attributed to the Hirmuse Formation (Pärnu core, 327.25-328.3 m: Meidla 1996, fig. 14) or to a new lithostratigraphic unit. A new name - the Variku Formation - is proposed for this claystone-siltstone bed (Fig. 2).

The Variku Formation is characterized by alternating dolomitic argillaceous quartzose siltstone, silty marl, and dolomitic claystone beds $10-50 \mathrm{~cm}$ in thickness (Fig. 4; Pl. I, figs. 1,2). Occasional calcareous marl or argillaceous limestone interbeds may be present in this interval. The silty beds of the Variku Formation contain abundant Chondrites and Zoophycos ichnofauna (Pl. I, fig. 1). For the type section we propose the interval of 401.1-409.9 $\mathrm{m}$ in the Ristiküla-174 core (Fig. 4; Ainsaar et al. 1996). The Variku Formation is distinguished also in the Kaagvere (259.6-267 m; Männil 1966), Tartu (Variku)-453 (288.3-299.1 m), Laeva-18 $(234.2-240.9 \mathrm{~m})$, and Viljandi-91 (325.5-333.9 m) core sections (Fig. 1). The thickness of the formation varies between 6 and $11 \mathrm{~m}$.

\section{Explanation of Plate I}

Core samples and scanning electron microscope (SEM) images of sedimentary rocks rich in quartz silt, from southern Estonia and Gotland.

Fig. 1. Quartzose siltstone with Chondrites and Zoophycos ichnofauna, Variku Formation, Ristiküla-174 core, $406.9 \mathrm{~m}$.

Fig. 2. Contact of siltstone (above, light) and claystone (below), Variku Formation, Tartu-453 core, $296.4 \mathrm{~m}$.

Fig. 3. Silty limestone (above, light) and siltstone (below), Gräsgård Siltstone, Grötlingbo core, $424.6 \mathrm{~m}$.

Fig. 4. Siltstone, SEM image from the sample in fig. 1, Variku Formation, Ristiküla-174 core, $406.9 \mathrm{~m}$.

Fig. 5. Siltstone, SEM image, Variku Formation, Tartu-453 core, $294.2 \mathrm{~m}$.

Fig. 6. Silty limestone, Gräsgård Siltstone, Grötlingbo core, $424.4 \mathrm{~m}$.

Fig. 7. Siltstone, SEM image from the lower part of the sample in fig. 3, Gräsgård Siltstone, Grötlingbo core, $424.6 \mathrm{~m}$.

Abbreviations: Q, quartz; F, feldspar; C, calcite; D, dolomite. 


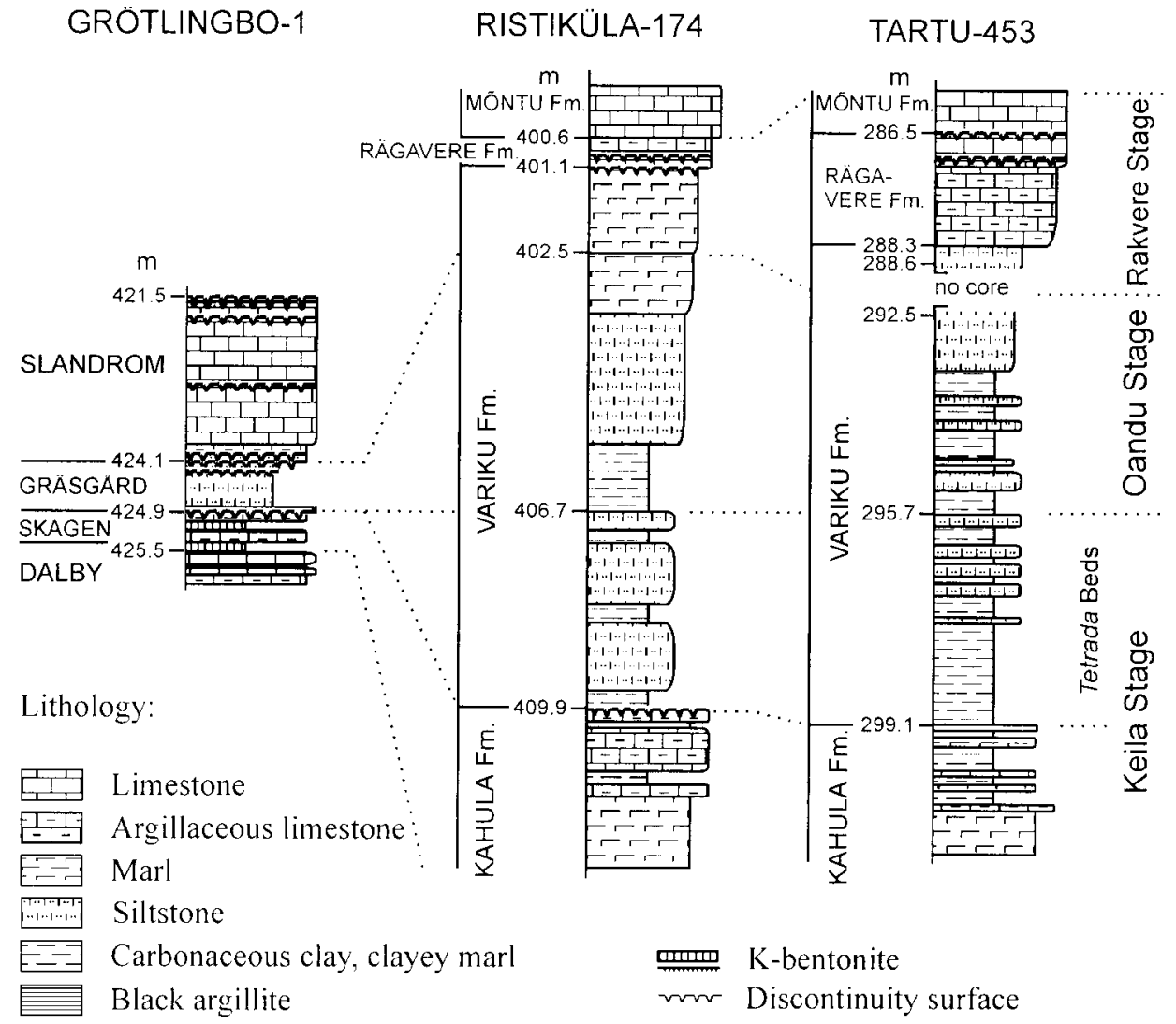

Fig. 4. Stratigraphy of core sections with silty sediments in Estonia and Gotland. Correlation (dotted lines) of southern Estonian sections based on ostracode data (Ainsaar et al. 1996, 1999b), correlation of stratigraphical units in Gotland according to Nõlvak \& Grahn (1993).

The Variku Formation overlies the Kahula Formation. The upper part of the Kahula Formation in central Estonia is highly argillaceous, composed mainly of marl with argillaceous limestone interbeds. Thus, the lower boundary of the Variku Formation is lithologically transitional, marked by the occurrence of intercalating siltstone and claystone beds and disappearance of limestone beds in the sections. The upper boundary of the formation is a relatively sharp contact between the marl or siltstone of the Variku Formation and the limestone of the Rägavere Formation.

\section{CORRELATION}

The lower boundary of the Keila Stage in Baltoscandia is tied to the prominent Kinnekulle K-bentonite bed (Bergström et al. 1995). This marker horizon can be 
recognized within the Kahula and Adze formations of the East Baltic and at the base of the Skagen Limestone in Sweden (Jaanusson 1995), which proves the correlation of these units suggested by micropalaeontological evidence (Fig. 2).

The age of the calcareous claystone of the Blidene Formation, overlying the Adze Limestone in the sections of the Livonian Tongue, has repeatedly been discussed in the literature (Männil 1966; Männil \& Meidla 1994; Hints \& Meidla 1997). Recent micropalaeontological evidence (Meidla 1996 and data from the Valga section) suggest the Keila age for this unit. This is indirectly supported also by the composition of the uppermost part of the Kahula Formation which may occasionally be relatively more argillaceous in the zone of facies transition (Ristiküla and Tartu core sections), and on this basis may be tentatively correlated with the Blidene Formation.

Various evidence is available of a remarkable hiatus at the Keila-Oandu transition in northern Estonia (e.g. Hints et al. 1989; Nestor \& Einasto 1997). This is confirmed by the microfauna and stable carbon isotope data (Ainsaar et al. 1999b; Kaljo et al. 1999; Meidla et al. 1999) which suggest that the uppermost beds of the Keila Stage are missing in central and northern Estonia (e.g. in the Pärnu and Rapla core sections; Fig. 2). This assumption is based on the absence of both the specific faunal elements (Pelecybolbina graesgardensis) and elevated carbon isotopic values in the sections of northern Estonia. In the Gotland area, the most prominent gap in the sequence is recognized in a similar position, between the Skagen Limestone (Keila Stage) and the upper Gräsgård Siltstone (Oandu Stage; Figs. 2, 4; Nõlvak \& Grahn 1993).

In southern Estonia, the beds with an elevated content of quartz silt (Variku Formation) fill in the sedimentary gap between the Kahula Formation (Keila Stage) and the marls of the Hirmuse Formation (Oandu Stage). The lower part of the Variku Formation (Tetrada beds in Ainsaar et al. 1999b) contains a relatively poor ostracode fauna with Tetrada pseudoiewica and several pre-Oandu taxa (Ainsaar et al. 1996; Meidla 1996). Ostracode faunas in the middle and upper parts of the Variku Formation are similar to those described from the Mossen Formation in southern Estonia (Meidla 1996).

The correlation of the Mossen Formation has been interpreted differently during the last decades (see Hints \& Meidla 1997 for a review). The Mossen Formation consists of the lower, black argillite member and the upper, Priekule Member (Ulst et al. 1982; Männil \& Meidla 1994). For the lower, unnamed part of the formation we propose the name Plunge Member. This name was introduced by Paškevičius (1994) in western Lithuania for the southern peripheral part of the same continuous argillite unit which is characteristic of Latvia and southern Estonia, and used later also in the Latvian part of the Jelgava Depression (Paškevičius 1997). The argillite of the Plunge Member is correlated with the uppermost part of the Keila Stage, the carbonaceous claystone of the Priekule Member with the Oandu and Rakvere stages (Meidla 1996; Hints \& Meidla 1997). 
The new data from the Mossen Formation of the Valga core are in agreement with the former consideration. The argillite of the Plunge Member contains abundant ostracodes Vogdesella subovata, typical of the same unit in the Abja and Taagepera sections of southern Estonia (Meidla 1996). In the Abja section, $V$. subovata is found together with Tetrada sp. (= T. pseudoiewica? in Ainsaar et al. 1999b) and Consonopsis consona (Meidla 1996), suggesting the correlation of the Plunge Member with the lowermost beds of the Variku Formation. The appearance of a new assemblage with Klimphores minimus, Easchmidtella fragosa, and Pseudoancora parovina is recorded $1 \mathrm{~m}$ above the argillite bed in the Valga section. This suggests that the lower boundary of the Oandu Stage is positioned in the lower part of the Priekule Member, inside claystones, in the sections of the Livonian Tongue. The distinction of the Rakvere Stage in the same area is based on the appearance of the ostracode association with Pelecybolbina pelecyoides, characteristic of the pure micritic limestone of the Rägavere Formation in central Estonia, of the upper part of the claystone of the Priekule Member (Mossen Formation) within the Livonian Tongue area, and recorded in the upper part of the siliciclastic deposits of the Variku Formation in the transitional zone. In summary, the available information suggests the penecontemporaneity of the Variku and Mossen formations and refers to the Oandu and Rakvere age of some parts of the Variku Formation (Fig. 2).

According to Jaanusson (Jaanusson \& Mutvei 1982), the Gräsgård Siltstone beds in subsurface of Gotland contain fauna typical of the Oandu Stage. Boulders of this rock have been found in southeastern Öland (Martna 1955), where both the Keila (Schallreuter 1977) and Oandu fauna (Jaanusson \& Mutvei 1982) can be recognized in different boulders. The boulders are probably derived from the area east of Öland, where these silty rocks may occur in a stratigraphically wider interval than in core sections of Gotland (Jaanusson \& Mutvei 1982). The overlying Lower Östersjö Limestone in northern Gotland and the Slandrom Limestone in southern Gotland are both tentatively considered as of RakvereNabala age, but their exact correlation with northern Estonian sections is unclear (Fig. 2; Grahn 1982; Nõlvak \& Grahn 1993).

\section{DISTRIBUTION OF LITHOFACIES}

The beginning of Oandu time tentatively marks the transition from the unification stage to the differentiation stage in the sedimentation history of the eastern part of the Baltoscandian Palaeobasin (Nestor 1990; Nestor \& Einasto 1997). This crucial rearrangement brought along drastic changes in the facies pattern, which are summarized in Fig. 5.

Lateral facies transition from argillaceous carbonate sediments of the North Estonian Confacies Belt to relatively more argillaceous rocks in the Livonian Tongue area in early Keila time was continuous (Fig. 5A), like it is characteristic of 

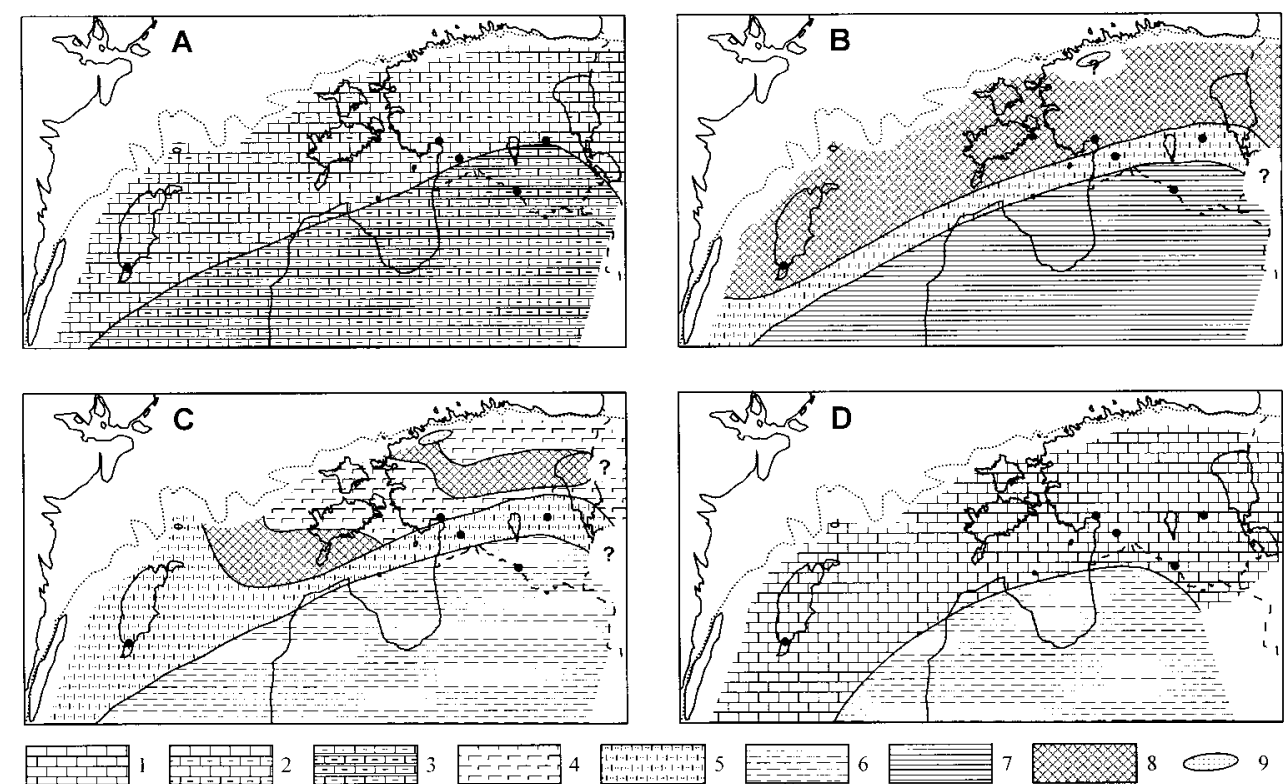

Fig. 5. Distribution of sediments and facies belts. (A) early Keila time; (B) late Keila time; (C) Oandu time (the latest part excluded); (D) Rakvere time. Lithology: 1, micritic limestone; 2, cyclical intercalation of pure and argillaceous limestone (wackestone); 3 , argillaceous limestone (wackestone) and marl; 4, marl; 5, silty sediments (siltstone and silty limestone in Gotland; intercalation of siltstone, silty marl, and claystone in Estonia); 6, claystone, carbonaceous claystone; 7, organic-rich argillite; 8, area of nondeposition/erosion; 9, shoal sediments (predominantly grainstones). Filled rings - sampled sections.

the unification stage. The lower ramp sediments of the Adze Formation differ from the upper ramp (in terms of Nestor \& Einasto 1997) sediments of the Kahula Formation mainly in the lack of pelletal material, in the elevated (20-75\%) content of i.r., and in the composition of skeletal debris (equally distributed brachiopod, trilobite, echinoderm, and bryozoan fragments in the Kahula Formation, predominantly trilobite fragments in the Adze Formation; Põlma 1972a, 1972b; Hints \& Põlma 1981). The Skagen Limestone in the Gotland area shows a great lithological similarity with the Kahula Formation of western Estonia. This is approved by the composition of skeletal debris of the corresponding interval in the File Haidar core (Martna 1955), which is more similar to the Kahula Formation (Põlma 1972b) than to the Adze Formation (Põlma 1972a). The similarity of the successions of the Gotland area and northern Estonia is emphasized by the gap in a similar position: at the top of the Skagen Limestone, on the Keila-Oandu boundary.

The absence of sediments of late Keila age in northern Estonia and the Gotland area and the existence of a wide nonsedimentation and/or erosion area in the upper ramp zone (Fig. 5B) is thought to be related to sea level drop (Kõrts et 
al. 1991; Ainsaar et al. 1996). This sea level change in late Keila time terminated the slowly seaward prograding highstand deposition of argillaceous carbonates (Kahula Formation) of late Haljala (Jõhvi) to Keila time (see Ainsaar 1990). The hiatus at the Keila-Oandu transition can thus be interpreted as type 1 sequence boundary (Van Wagoner et al. 1988).

Sedimentary rocks of the Variku Formation of late Keila to early Rakvere age form a 30-50 km wide belt of siliciclastic mudstones with an elevated content of coarse quartz silt in southern Estonia, bordering the clay-dominated facies within the Livonian Tongue. The abundance of erratic boulders of siltstone or silty limestone in Öland Island, with fauna indicating both the Keila and Oandu age (Martna 1955; Schallreuter 1977), show that this facies belt extended to the western part of the Baltic Sea already in late Keila time (Fig. 5B). Claystone and siltstone beds in the lower part of the Variku Formation grade in the southern (offshore) direction into the organic-rich claystones (Plunge Member) or pure claystones (lowermost part of the Priekule Member). There are lithologically transitional sections between the distribution areas of the Variku and Mossen formations, characterized by claystones, but without siltstone and black argillite beds, like Ruhnu-500 (638.8-645.7 m). The occurrence of the well-differentiated facies pattern in late Keila time may be interpreted as the beginning of the differentiation stage in basin development.

The sedimentation of organic-rich mud (Plunge Member) within the Livonian Tongue in late Keila time can be explained as an episode of flooding after the regression. In a transgressive situation, it could be taken as an evidence of stratification of the sea. The lower boundary of the Variku Formation and approximately the correlative lower boundary of the Mossen Formation could be regarded in this case as a transgressive surface which is correlated with the hiatus in northern Estonia. This transgressive surface may mark a sequence boundary in the offshore area due to the absence of the lowstand deposits of late Keila age. The flooding may be partly responsible for the hiatus, as such deepening episodes are often accompanied by nondeposition or erosion in onshore areas (Van Wagoner et al. 1988). The faunal change at the lower boundary of the Oandu Stage in northern Estonia (Männil 1966; Rõõmusoks 1972; Hints et al. 1989; Kaljo et al. 1995) can also be traced in the offshore area. It is recognized in the middle of the siliciclasticdominated unit (Meidla 1996; Ainsaar et al. 1999a; Meidla et al. 1999), thus indicating that the boundary of the Oandu Stage is located higher of the sequence boundary.

Sea level rise and flooding of the onshore areas introduced the accumulation of mixed carbonate-argillaceous muddy sediments (marls) of Oandu age (Hirmuse Formation) which covered transgressively the nondeposition surface. The Hirmuse Formation occurs in two separated distribution areas in northern Estonia (Fig. 5C). This particular distribution pattern may suggest the existence of submarine nonsedimentation belts or be a result of postsedimentational removal of the material. However, it may also be due to patchy distribution of the 
basal transgressive strata as suggested by Hints (1998). In southern Estonia the marls of the Hirmuse Formation grade into the silty siliciclastic beds of the Variku Formation.

In the Gotland area the silty facies of Oandu age is more widely distributed than that of late Keila age. The Gräsgård Siltstone bed is transgressively overlying the hiatus on top of the Skagen Limestone. Compared to the Variku Formation, the Gräsgård Siltstone is almost nondolomitic, more fossiliferous, and lacks claystone interbeds. An ichnofauna recorded in the Gräsgård Siltstone (Teichichnus or Zoophycos? in Martna 1955, fig. 3 on p. 239) is similar to that found in the Variku Formation (Pl. I, fig. 1). This is an additional evidence for considering the Gräsgård Siltstone as a western facies analogue and extension of the siltstone beds of the Variku Formation.

The main reason for facies differentiation of these siliciclastic beds could be the hydrodynamic fractionation of terrigenous material. Although the size of quartz grains and clay agglomerates might be similar in normal saline seawater, the heavier quartz grains settled in the shoal area (northwestern Estonia) and in low energy environment closer to the input area, while clay material could be distributed more evenly over the basin. There is no direct evidence from the Baltic Basin of the deposition of terrigenous shoal sands of Caradoc age. The prehiatus limestone beds (uppermost part of the Kahula Formation, Saue and Lehtmetsa members) and post-hiatus limestone strata (Saku Member of the Vasalemma Formation) contain thin, sometimes cross-bedded layers enriched in coarse silt (Männil 1960; Põlma et al. 1988). These rocks represent a probable flank facies of the shoal grainstones of the Vasalemma Formation and are formed in the wave action zone. The similar grain size of terrigenous quartz and feldspar in shoal siltstone beds and in offshore muddy siltstone beds shows the absence of fresh clastic material input into the basin. It is possible that older Vendian and Cambrian claystones and siltstones were exposed during the sea level drop, and the silty accumulations in southern Estonia and eastern Sweden may have been formed as reworking products of these sediments during the sea level drop and the following flooding.

The pure calcareous mud covered the older sediments in northern/central Estonia in the latest Oandu and Rakvere time (Fig. 5D). Similar sediments are distributed in the northern Gotland area (Lower Östersjö Limestone). Calcareous, finely nodular or bedded micritic limestone (Slandrom Limestone) is also widespread in the neighbouring areas of the Central Baltoscandian Confacies Belt. The Slandrom Limestone is considered as the wedge of the pure micritic limestone deposition of the North Estonian Confacies Belt (Lower Östersjö Limestone in the northern Gotland area; Rägavere, Paekna, and Saunja formations in northern Estonia; Fig. 3; Jaanusson 1982). Formation of clay-rich sediments (upper part of the Priekule Member) continued during Rakvere time within the Livonian Tongue. 


\section{CARADOC TURNOVER SCENARIO}

The change from carbonate-dominated to fine siliciclastic-dominated sedimentation in late Keila time in the offshore part of the basin, in the Livonian Tongue and in the transitional belt surrounding it, was an extraordinary event having not analogues in the Baltoscandian basin since the Arenig. The change in the type of sedimentation was caused by an increase in terrigenous fine-grained quartz input into the basin and increasing water turbidity, together with increasing clay input inhibiting the carbonate production. This might have been initiated by a eustatic sea level fall and continued during the following sea level rise (drowning).

A similar and nearly contemporaneous change from carbonate-dominated to siliciclastic-rich sedimentation is described from the eastern part of North America (Holland \& Patzkowsky 1996, 1997). This change coincides in this area with a major sea level rise and faunal change at the M4/M5 sequence boundary above the Millbrig K-bentonite bed. The correlative late Keila and M4/M5 sequence boundaries in two continents may be the results of the same eustatic sea level change which was also responsible for increasing siliciclastic influx into the carbonate basins. However, the increased influx of terrigenous silt and clay into the carbonate basin of North America may be ascribed to the Taconic orogeny (Holland \& Patzkowsky 1996, 1997).

In the Baltoscandian Palaeobasin, the Caradoc turnover was a complex event (Fig. 6). It developed on the background of a gradual climatic change from moderate to tropical during Keila-Oandu time, resulting generally from the continental drift (Jaanusson 1973; Webby 1984; Nestor \& Einasto 1997) and including a succession of events: (1) change in the carbon isotopic composition of seawater in Keila time, possibly of global character (Ainsaar et al. 1999b), related to a change in sea stratification and/or organic productivity; (2) possibly eustatic sea level fall in late Keila time and a following transgression(s) lasting from late Keila to early Rakvere time; (3) increased input of siliciclastic clay and silt into the basin during late Keila and Oandu time, initiated by sea level change; (4) appearance of new fauna at the boundary between the Keila and Oandu stages, possibly reflecting a global change (Meidla et al. 1999). Such a sequence of related events suggests a global oceanographic background, and a change in the type of sedimentation fits with this scenario.

As one possible factor, which may have controlled this process of the Caradoc turnover we could mention the fluctuation of the continental ice sheet in Gondwana. Although recent papers advocate for a short-lived end-Ordovician glaciation, and the beginning of continental glaciation already in the Caradoc has no direct evidences yet (see Brenchley et al. 1994), the last viewpoint is supported by several authors (Lavoie 1995; Nestor \& Einasto 1997; Pope \& Read 1998) and might explain the changes in eustatic sea level and in isotopic composition, and subsequently also in sedimentary input and fauna. 


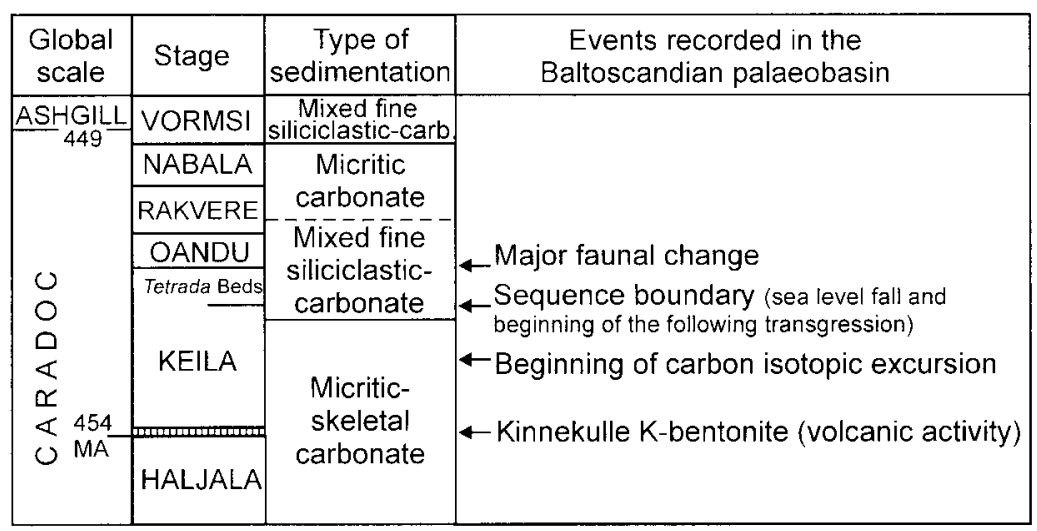

Fig. 6. Relative timing of the sedimentological, geochemical, and faunal events in the Baltoscandian Palaeobasin. A gradual climatic change from temperate to warm-water basin took place during the same period.

\section{CONCLUSIONS}

The transition from the onshore North Estonian Confacies Belt to the offshore Central Baltoscandian Confacies Belt in the middle Caradoc (Keila-Rakvere) stratigraphic interval is characterized by the distribution of a rock unit of intercalating quartzose siltstones, claystones, and marls. The name "Variku Formation" is proposed for this particular rock unit. According to ostracode data, the Variku Formation can be subdivided between the Keila, Oandu, and Rakvere stages.

The lower boundary of the Variku Formation and approximately the correlative lower boundary of the Mossen Formation can be regarded as a transgressive surface which grades into the unconformity in northern Estonia and serves as a sequence boundary in this area.

The Caradoc turnover and change of deposition type in the Baltic Basin was a complex event which lasted for a considerable time (Fig. 6). It can be described as a succession of events, probably caused by global oceanographic changes.

\section{ACKNOWLEDGEMENTS}

The authors are grateful to colleagues from the Estonian Geological Survey, Institute of Geology at Stockholm University, and Institute of Geology at Tallinn Technical University for access to the core material. We also thank U. Sturesson, K. Kirsimäe, and T. Klaos for help with the analytical sections and S. Jensen for valuable remarks on trace fossils. This work was supported by the Estonian Science Foundation (grant No. 3011) and was partly completed when L. A. was a visiting scholar of the Swedish Institute at the University of Uppsala. 


\section{REFERENCES}

Ainsaar, L. 1990. On the kukersite layers in the Jõhvi and Keila Regional Stages in Estonia. Acta Comment. Univ. Tartuensis, 885, 95-108 (in Russian).

Ainsaar, L., Kirsimäe, K. \& Meidla, T. 1996. Regression in Caradoc: evidences from southwestern Estonia (Ristiküla core). In WOGOGOB-94 Symposium, Working Group of Ordovician Geology of Baltoscandia, Bornholm-94 (Stouge, S., ed.). Geol. Surv. Den. Greenl. Rep., 98, $5-12$.

Ainsaar, L., Martma, T., Meidla, T., Rubel, M. \& Sidaravičiene, N. 1999a. Quantitative stratigraphy of sedimentary sequences: a case study of the Middle Ordovician event. In Computerized Modeling of Sedimentary Systems (Harff, J., Lemke, W. \& Stattegger, K., eds.), pp. 275287. Springer-Verlag, Berlin.

Ainsaar, L., Meidla, T. \& Martma, T. 1999b. Evidence for a widespread carbon isotopic event associated with late Middle Ordovician sedimentological and faunal changes in Estonia. Geol. Mag., 136, 49-62.

Bergström, S. M., Huff, W. D., Kolata, D. R. \& Bauert, H. 1995. Nomenclature, stratigraphy, chemical fingerprinting, and areal distribution of some Middle Ordovician K-bentonites in Baltoscandia. $G F F, 117,1-13$.

Brenchley, P. J., Marshall, J. D., Carden, G. A. F., Robertson, D. B. R, Long, D. G. F., Meidla, T., Hints, L. \& Anderson, T. F. 1994. Bathymetric and isotopic evidence for a short-lived late Ordovician glaciation in a greenhouse period. Geology, 22, 295-298.

Grahn, Y. 1982. Caradocian and Ashgillian Chitinozoa from the subsurface of Gotland. Sver. Geol. Unders. Ser. C, $\mathbf{7 8 8}$.

Hints, L. 1998. Oandu Stage (Caradoc) in central North Estonia. Proc. Estonian Acad. Sci. Geol., 47, 158-172.

Hints, L. \& Meidla, T. 1997. Keila Stage, Oandu Stage, Rakvere Stage. In Geology and Mineral Resources of Estonia (Raukas, A. \& Teedumäe, A., eds.), pp. 74-80. Estonian Acad. Publ., Tallinn.

Hints, L. \& Põlma, L. 1981. Distribution of macrofossils and skeletal debris in the East Baltic Middle Ordovician. Proc. Acad. Sci. ESSR. Geol., 30, 89-97 (in Russian).

Hints, L., Meidla, T., Nõlvak, J. \& Sarv, L. 1989. Some specific features of the Late Ordovician evolution in the Baltic basin. Proc. Acad. Sci. ESSR. Geol., 38, 83-87.

Holland, S. M. \& Patzkowsky, M. E. 1996. Sequence stratigraphy and long-term paleoceanographic change in the Middle and Upper Ordovician of the eastern United States. In Paleozoic Sequence Stratigraphy: Views from the North American Craton (Witzke, B. J., Ludvigson, G. A. \& Day, J., eds.). GSA Spec. Pap., 306, 117-129.

Holland, S. M. \& Patzkowsky, M. E. 1997. Distal orogenic effects on peripheral bulge sedimentation: Middle and Upper Ordovician of the Nashville Dome. J. Sedim. Res., 67, 250-263.

Jaanusson, V. 1973. Aspects of carbonate sedimentation in the Ordovician of Baltoscandia. Lethaia, 6, 11-34.

Jaanusson, V. 1976. Faunal dynamics in the Middle Ordovician (Viruan) of Balto-Scandia. In The Ordovician System: Proceedings of a Palaeontological Association Symposium, Birmingham, September 1974 (Bassett, M. G., ed.), pp. 301-326. Univ. Wales Pr., Cardiff.

Jaanusson, V. 1982. Introduction to the Ordovician of Sweden. In Field Excursion Guide, IV International Symposium on the Ordovician System (Bruton, D. L. \& Williams, S. H., eds.). Paleont. Contrib. Univ. Oslo, 279, 1-9.

Jaanusson, V. 1995. Confacies differentiation and upper Middle Ordovician correlation in the Baltoscandian basin. Proc. Estonian Acad. Sci. Geol., 44, 73-86.

Jaanusson, V. \& Mutvei, H. 1982. Ordovician of Öland: Guide to Excursion 3, IV International Symposium on the Ordovician System, Oslo 1982. Stockholm. 
Kaljo, D., Hints, L., Hints, O., Martma, T. \& Nõlvak, J. 1999. Carbon isotope excursions and coeval environmental and biotic changes in the late Caradoc and Ashgill of Estonia. Acta Univ. Carolinae Geologica, 43, 507-510.

Kaljo, D., Nõlvak, J. \& Uutela, A. 1995. Ordovician microfossil diversity patterns in the Rapla section, northern Estonia. In Ordovician Odyssey: Short Papers for the Seventh International Symposium on the Ordovician System, Las Vegas, Nevada, USA, June 1995 (Cooper, J. D., Droser, M. L. \& Finney, S. C., eds.), pp. 415-418. The Pacific Section Society for Sedimentary Geology, Fullerton.

Kõrts, A., Männil, R., Põlma, L. \& Einasto, R. 1991. Epochs and depositional environments of kukersite-type (algal) organic matter accumulation in the Ordovician and Silurian of Estonia. In Major Biological Events in Earth History: Transactions of the XXXII Session of All-Union Palaeontological Society (Kaljo, D., Modzalevskaya, T. \& Bogdanova, T., eds.), pp. 87-95. Tallinn (in Russian).

Laškov, E., Paškevičius, J. \& Sidaravičiene, N. 1984. Lithostratigraphic subdivision of the Ordovician rocks of the Central Lithuanian Depression. In Stratigrafiya drevnepaleozojskikh otlozhenij Pribaltiki (Männil, R. \& Mens, K., eds.), pp. 77-93. Acad. Sci. Estonian SSR, Tallinn (in Russian).

Lavoie, D. 1995. Late Ordovician high-energy temperate-water carbonate ramp, southern Quebec, Canada: implications for Late Ordovician oceanography. Sedimentology, 42, 95-116.

Männil, R. 1960. The stratigraphy of the Oandu ("Vasalemma") Stage. Eesti NSV TA Geol. Inst. Uurimused, 5, 89-122 (in Russian).

Männil, R. 1966. Evolution of the Baltic Basin During the Ordovician. Valgus, Tallinn (in Russian).

Männil, R. \& Meidla, T. 1994. The Ordovician System of the East European Platform (Estonia, Latvia, Lithuania, Byelorussia, parts of Russia, the Ukraine and Moldova). In The Ordovician System of the East European Platform and Tuva (Southeastern Russia): Correlation Charts and Explanatory Notes (Webby, B. D., Ross, R. J. \& Yong, Y. Zhen, eds.). IUGS Publ., 28, part A.

Martna, J. 1955. Studies on the Macrourus and Slandrom Formations I. GFF, 77, 229-256.

Meidla, T. 1996. Late Ordovician ostracodes of Estonia. Fossilia Baltica, 2.

Meidla, T., Ainsaar, L., Hints, L., Hints, O., Martma, T. \& Nõlvak, J. 1999. The mid-Caradocian biotic and isotopic event in the Ordovician of the East Baltic. Acta Univ. Carolinae Geologica, 43, 503-506.

Nestor, H. 1990. Basin development and facies models. In Field Meeting, Estonia 1990: An Excursion Guidebook (Kaljo, D. \& Nestor, H., eds.), pp. 33-36. Estonian Acad. Sci., Tallinn.

Nestor, H. \& Einasto, R. 1997. Ordovician and Silurian carbonate sedimentation basin. In Geology and Mineral Resources of Estonia (Raukas, A. \& Teedumäe, A., eds.), pp. 192-204. Estonian Acad. Publ., Tallinn.

Nõlvak, J. 1997. Ordovician, Introduction. In Geology and Mineral Resources of Estonia (Raukas, A. \& Teedumäe, A., eds.), pp. 52, 54-55. Estonian Acad. Publ., Tallinn.

Nõlvak, J. \& Grahn, Y. 1993. Ordovician chitinozoan zones from Baltoscandia. Rev. Palaeobot. Palynol., 79, 245-269.

Paškevičius, J. 1994. Ordovikas. In Lietuvos Geologija (Grigelis, A. \& Kadunas, V., eds.), pp. 4667. Mokslo ir Enciklopediju Leidykla, Vilnius.

Paškevičius, J. 1997. The Geology of the Baltic Republics. Lietuvos geologijos tarnyba, Vilnius.

Põldvere, A., Meidla, T., Bauert, G., Bauert, H. \& Stouge, S. 1998. Ordovician. In Tartu (453) Drillcore (Männik, P., ed.). Estonian Geol. Sections, 1, 11-17.

Põlma, L. 1972a. Skeletal debris content and composition in the sediments of the East Baltic Ordovician facial axial belt (Engure boring). Eesti NSV TA Toim. Keemia Geol., 21, 148 154 (in Russian). 
Põlma, L. 1972b. Skeletal debris content and composition in the sediments of the northern facial belt of the East Baltic Ordovician (Rapla boring). Eesti NSV TA Toim. Keemia Geol., 21, 326-332 (in Russian).

Põlma, L. 1982. Comparative Lithology of the Ordovician Carbonate Rocks in the Northern and Middle East Baltic. Valgus, Tallinn (in Russian).

Põlma, L., Sarv, L. \& Hints, L. 1988. Lithology and Fauna of the Caradoc Series Type Sections in North Estonia. Valgus, Tallinn (in Russian).

Pope, M. \& Read, J. F. 1998. Ordovician metre-scale cycles: implications for climate and eustatic fluctuations in the central Appalachians during a global greenhouse, non-glacial to glacial transition. Palaeogeogr., Palaeoclimatol., Palaeoecol., 138, 27-42.

Rõõmusoks, A. 1972. Stratigraphic breaks in the Ordovician of northern Estonia and the corresponding changes in the fauna. In International Geological Congress, 24th Session, Canada - 1972, Section 7, Paleontology (Mamet, B. L. \& Westermann, G. E. G., eds.), pp. 605-611. Montreal.

Schallreuter, R. E. L. 1977. Eine neue Art der Ostrakodengattung Pelecybolbina aus dem Ordoviz von Öland. GFF, 99, 409-411.

Torsvik, T. H., Smethurst, M. A., Meert, J. G., Van der Voo, R., McKerrow, W. S., Brasier, M. D., Sturt, B. A. \& Walderhaug, H. J. 1996. Continental break-up and collision in the Neoproterozoic and Palaeozoic - a tale of Baltica and Laurentia. Earth-Sci. Rev., 40, 229258.

Ulst, R. Zh., Gailite, L. K. \& Yakovleva, V. I. 1982. Ordovik Latvii. Zinatne, Riga (in Russian).

Van Wagoner, J. C., Posamentier, H. W., Mitchum, R. M., Vail, P. R., Sarg, J. F., Loutit, T. S. \& Hardenbol, J. 1988. An overview of the fundamentals of sequence stratigraphy and key definitions. In Sea-level Changes: An Integrated Approach (Wilgus, C. K., Hastings, B. S., Kendall, C. G. St. C., Posamentier, H. W., Ross, C. A. \& Van Wagoner, J. C., eds.). SEPM Spec. Publ., 42, 39-45.

Webby, B. D. 1984. Ordovician reefs and climate: a review. In Aspects of the Ordovician System (Bruton, D. L., ed.). Palaeont. Contrib. Univ. Oslo, 295, 89-100.

\title{
KESK-CARADOCI TERRIGEENSETE-KARBONAATSETE SEGASETENDITE FAATSIESED JA STRATIGRAAFIA BALTOSKANDIA IDAOSAS
}

\author{
Leho AINSAAR ja Tõnu MEIDLA
}

On uuritud Baltoskandia paleobasseini konfaatsieste üleminekuala settekivimeid ja faatsieste dünaamikat Keila, Oandu ja Rakvere eal Lõuna-Eesti ja Gotlandi piirkonnas. Vähekarbonaatsete peenpurdkivimite mittekarbonaatse komponendi terasuuruse analüüs näitas erinevusi fatsiaalsete vööndite vahel. On püstitatud uus, kahe suurfaatsiese üleminekualal leviv litostratigraafiline üksus Variku kihistu, mida iseloomustab aleuroliidi, savi ja merglikihtide vaheldumine. Ostrakoodide andmetele toetudes on esitatud Variku kihistu vanus (Keila kuni Rakvere iga) ja korrelatsioon külgneva Mosseni kihistuga. Basseini üldine settimistüübi muutus kestis Caradocis arvestatava aja ning seisnes kliima, merevee isotoopkoostise, meretaseme ja setete sissekande teisenemises. Sellel basseini arengu pöördeprotsessil olid ilmselt komplekssed mandritriivi ja mandrijäätumistega seotud põhjused. 


\title{
ФАЦИИ И СТРАТИГРАФИЯ СРЕДНЕКАРАДОКСКИХ СМЕШАННЫХ ТЕРРИГЕННО-КАРБОНАТНЫХ ПОРОД В ВОСТОЧНОЙ ЧАСТИ БАЛТОСКАНДИИ
}

\author{
Лехо АЙНСААР и Тыну МЕЙДЛА
}

\begin{abstract}
В Южной Эстонии и в окрестностях о-ва Готланд изучены осадочные породы и динамика фаций кейлаского, оандуского и раквереского возраста на переходе конфациальных зон палеобассейна Балтоскандии. Гранулометрический анализ некарбонатного компонента малокарбонатных мелкообломочных пород указывает на различия основных фациальных зон. В переходной зоне двух конфаций в Южной Эстонии установлено новое литостратиграфическое подразделение - варикуская свита с характерным для нее переслаиванием малокарбонатных алевролитов, глин и мергелей. По остракодам определен возраст варикуской свиты как кейлараквереский, и показана ее корреляция с моссенской свитой. Переход на новый тип седиментации в карадоке продолжался длительное время в соответствии с изменениями климата, изотопного состава океанической воды, уровня моря и привноса осадочного материала. Показаны комплексные причины этих явлений и возможная связь с дрейфом материков и оледенением.
\end{abstract}

